\title{
THE TASTES FROM PORTUGAL: FOOD AS REMEMBRANCE IN PORTUGUESE AMERICAN LITERATURE
}

\author{
Reinaldo Silva \\ Universidade de Aveiro, Portugal
}

Contemporary Portuguese American literature written by Thomas Braga (1943-), Frank Gaspar (1946-), and Katherine Vaz (1955-) share a profusion of topics - with ethnic food being, perhaps, the most representative one. What these writers have in common is that their roots can be traced to Portugal's Atlantic islands - the Azores - and not to continental Portugal. They are native Americans and write in English, though their characters and themes are Portuguese American. Some of them lived close to the former New England whaling and fishing centers of New Bedford and Nantucket, which Herman Melville has immortalized in Moby-Dick and in his short story, "The "Gees," in The Piazza Tales. These seaports were renowned worldwide and eventually attracted Azorean harpooners. The Azorean background of Thomas Braga and Frank Gaspar helps us to understand why fish and seafood feature so extensively in their writings instead of dishes containing meat as is the case in the fiction of Katherine Vaz. 
In these authors' works, writing about food is a means for ethnic identity and cultural preservation - especially in a multiethnic country as the United States of America where the official discourse in the past encouraged forgetfulness. And this meant forgetting one's ethnic background and anything associated with it so as to not be labelled an "unmeltable." In contemporary Portuguese American literature, food is a means to keep alive certain traditions in the ethnic enclaves of America, a land that, on occasion, has been hostile towards Otherness. In addition, food is an important anchor for ethnic identity and a means to connect with times which have completely disappeared. These authors' argument about food and cultural preservation, however, cannot be fully appreciated without an understanding of how they relate to the homeland, religion, the garden, and music. By confronting their writings about food, one is reminded of a kaleidoscope where a central topic, food, encompasses a myriad of themes or angles of perception. The depth and richness of the former cannot fully be appreciated without a glance at the latter.

Caldo verde, the popular green cabbage soup that Jean Anderson considers "the national dish of Portugal,"11 appears profusely in Frank X. Gaspar's first collection of poems, The Holyoke (1988), winner of the 1988 Morse Poetry Prize. Gaspar is the grandson of immigrants who came to Provincetown, Massachusetts, from the island of Pico, in the Azores. He is also the author of two additional award-winning collections of poetry. While The Holyoke comprises only eight poems touching upon Portuguese American issues, Mass for the Grace of a Happy Death (1994), winner of the 1994 Anhinga Prize for Poetry, contains even fewer. Most of the poems in this collection range from the poet's days in the navy during Vietnam to his days as an undergraduate and graduate student in California and depict life in the Golden State, the drought, illegal Mexican immigrants being assisted by family members, the youth culture of the 1960s, the 1970s road culture, women, and sex. Practically all the poems in A Field Guide to the Heavens (1999), winner of the 1999 Brittingham Prize in Poetry, are about California, the poet's home. In the novel, Leaving Pico (1999), Gaspar probes deeper into his ancestral culture through Josie and his grandfather, John Joseph, 


\section{Ethnic Studies Review Volume 31}

who, in the course of the story, tells Josie the tale of Carvalho, an adventurous explorer and competitor of Christopher Columbus. Leaving Pico gives a very detailed and engrossing portrayal of life in a Portuguese ethnic enclave in the United States. In his fourth collection of poems, Night of a Thousand Blossoms, published in 2004, references to ethnicity are scarce. ${ }^{2}$

"Tia Joanna" (Aunt Joanna), the third poem in Part One of The Holyoke, focuses on the religious zeal of a Portuguese immigrant woman and is also laden with references to food, especially Gaspar's favorite caldo verde soup, which, in this poem, he refers to as kale soup. This collection has three parts and it tells the "old story: a young man's passage from boyhood to maturity, in a small town by the sea. His people are Portuguese and Catholic." ${ }^{3}$ This work deals with a boy's growth and how nature and the community assist the process of maturation. Tia Joanna is depicted as a devout woman who spends much of her time in church either praying the rosary, going to confession, or experiencing a mystical union with God. Her patriarchal culture, however, demands that her presence in the kitchen and her role as a housewife never be neglected or sacrificed despite her religious fervor. Perhaps the poem's uniqueness lies in the manner in which it captures how Provincetown Portuguese women reconcile their spiritual lives with their role as housekeepers and wives of fishermen. While she is enjoying the ambiance of stillness, the murmur of voices in the confessional, and the flickering candles in her community church, Tia Joanna reflects on the bonds connecting her to the other women in church on that particular day. While they are all dressed in dark clothes, they are also very hard-working, devout, and unquestioning of their roles as housekeepers and cooks:

The soft kerchiefs

of the women, the dark cloth

of their long coats, the kale cooking

on the oilstoves in the redolent kitchens,

the checkered shirts of the husbands,

the fish they bring to the doorways... (7-8). 
In this quote, we are invited to peek into these immigrants' kitchens and witness their simple ways and dress. Her wearing dark clothes may be her way of responding to the death of a loved one at sea or simply a cultural practice. Moreover, it stresses the gender roles in this culture, where the Portuguese fishermen readily give up their active, enterprising activity as soon as "the fish they bring to the doorways" is handed to their wives for them to gut and cook. Wishing she could prolong her prayers, her mystical experience with God, and eventually eating from God's holy body through "the host she will receive," Tia Joanna is fully aware that

tonight still there is mackerel to pickle

with vinegar and garlic in the stone crock, her husband's silver hair to trim, the bread

to set rising in the big china bowl

on the stool tucked close to the chimney (7-8).

This quote foregrounds the kitchen as a woman's place in this New England immigrant fishing community and how women exercise their power there. The frugal meal consisting of kale soup and home baked bread, along with the mackerel she is preparing for other meals, stress this couple's relative poverty and simplicity. But as long as her husband has the strength to go out to sea and she grows her cabbages in her garden, there will always be something to put on their table. The knowledge that they will never starve in times of need is, certainly, re-assuring. This poem further stresses this woman's self-reliance, her independence, mothering, the power of the mother, as well as traditional gender roles which enhance the symbolism of the garden. In this sense, references to food and growing a vegetable garden are a common feature in most contemporary Portuguese American literature and this propensity to gardening still a customary practice in Portuguese communities in the United States. ${ }^{4}$

Kale soup is on the dinner table of Gaspar's Leaving Pico (1999), a novel about Azorean immigrant life in Provincetown and how this community reacts and resists to American ways. Leaving Pico captures quite well life in this ethnic enclave in the 1950s, 


\section{Ethnic Studies Review Volume 31}

the antagonism between the Portuguese from the Azores islands, represented by the family of Josie, the story's narrator and grandson of John Joseph Carvalho, and the Lisbons, that is, those from the mainland Portugal, represented by Carmine, who is courting Josie's mother, Rosa. In a passage where the narrator, who is still a young boy of about twelve or thirteen, is complaining to his Uncle Paddy and great aunt Theophila about how the family avoids talking about the past and its secrets, we learn that they were all "eating kale soup at the kitchen table, a little past noon" (149)..$^{5}$ In this novel, ethnic eating is intimately connected with the vegetables grown in the immigrant's garden. During an episode when the neighbors try to extinguish the fire in Josie's house, Josie tells us that "Our little garden had been trampled, and kale and turnips lay crushed on the wet ground" (176). The garden provides sustenance to these poor immigrants, but for the older generations it is also a means to preserve one's ethnic identity and ancestral rural way of life. It also offers a retreat from the alienating conditions imposed by the factory, commercial fishing, the whaling or dairy industries, and intensive farming - activities in which the first generations of Portuguese immigrants excelled in the three traditional areas of settlement in the United States: New England, California, and Hawaii. The Portuguese communities in the New Jersey and New York areas are more recent, going back to the beginning of the twentieth-century, and are composed mostly of continental Portuguese, whereas the Azorean communities go back at least to the beginning of the nineteenth-century. A vegetable garden grown in the backyard characterizes Portuguese immigrant life in the United States, especially the first and second generations, who are adamant about erasing an ancestral rural way of life and yet do not wish to do away with the spiritual connection with the old country such a garden provides.

But why is food such an important element in Gaspar's work and why has it been an incentive for his writing? When I asked Gaspar about this, he generously shared the following with me: ${ }^{6}$ "Certainly," he writes, food "is the link with my heritage that is the strongest in that it is unaffected by time." The old people "pass on, the fishing industry is replaced by tourism, the wharves decay, 


\section{Silva-The Tastes from Portugal}

the old houses are bought up by yuppies and gentrified, the old Portuguese ways fade, but the food is always there. I can have it in my kitchen whenever I want." Food also functions as an anchor connecting to a past that has completely disappeared. "Like the petite Madeleine in Proust's À la Recherche du Temps Perdu," he notes, "the food conjures up the memories - the very PRESENCE of that vanished world."

For Gaspar, Portuguese food is a means through which he preserves a vanishing way of life in Provincetown, in a time when the Portuguese were the dominant ethnic group there. As for his favorite dishes, Gaspar says that "There is sweet bread on the top of my refrigerator right now. My son and I heat it for breakfast. We don't always have it, but often." Gaspar also stresses the vanishing social customs and the Americanization of ethnic foodways since he claims that his one "'gourmet" dinner that [he] cook[s] for guests is Portuguese Stuffed Sea Clams." Moreover, he does "about two or three kale soups a year." This may be due to his being away from the homeland or of seldom visiting the homeland of his ancestors. I think because taste and smell are such strong senses, we writers tend to use them to evoke a place or time. Whenever I'm back in Provincetown, I dine almost exclusively on Portuguese food as it's found in all the little restaurants (not the new yuppie ones, of course). I like especially codfish, baked haddock, flippers... and vinho d'alhos. Mackerel or pork for those.

The irony is that some of these recipes as, for example, the Portuguese Stuffed Sea Clams, are not genuinely Portuguese; instead, they have been adapted - or Americanized - to meet the local Cape Cod taste and are also utilized because of the abundance of clams in this region. In most Portuguese recipes containing clams (amêijoas) such as, for example, amêijoas à algarvia, amêijoas à bulhão pato, amêijoas de caldeirada, and amêijoas à guincho, the clams are - depending on the recipe itself - seasoned only with olive oil, garlic, bay leaves, parsley, salt, pepper, coriander, lemon, onions, and tomatoes. ${ }^{7}$ Gaspar's clam recipe suggests a range of additional ingredients which the author, unfortunately, does not specify. One reason the works of Gaspar are saturated with references to fish and seafood is that he is a Provincetown/New 


\section{Ethnic Studies Review Volume 31}

England writer and, for that matter, tries to capture the livelihood of Portuguese fishermen he witnessed in this region. Presumably, fish was a regular presence on the family's table. In addition, he is also heir to a culture in which the sea has loomed so strongly since the Renaissance, especially with the Age of European Discoveries. It was simply impossible for him to ignore the presence - or proximity to - the Atlantic Ocean in his ethnic community as well as his ancestral seafaring cultural heritage in Leaving Pico.

Gian-Paolo Biasin's argument on the ways in which novelists often use meals in a narrative fits Leaving Pico quite well. ${ }^{8}$ In this novel, there are two clambakes that provide an intense look at the relationships of characters and food. Both episodes are a means for the characters to get together, socialize, and to connect with the ancestral culture through food, singing, and listening to fado. ${ }^{9}$ In the first episode, food allows for a clash between the values of the local Portuguese immigrants who retain an attitude of alienation and suspicion towards individuals from the mainstream and John Joseph, whose openness is gradually eroding these values. During this episode, they celebrate the annual ritual of the Blessing of the Fleet, on the first Sunday in June, whereas in the second they have gotten together to mourn the death of John Joseph, Josie's grandfather, who was shipwrecked. During the first clambake, in addition to the local Provincetown Portuguese immigrants, a gay couple, Roger and Lew, who have rented an upper room for the Summer season at Josie's house are present; the two women, Cynthia and Amalia, John Joseph is flirting with, are also present. John Joseph is, unlike most first-generation Portuguese immigrants, willing to interact with individuals from beyond his ethnic enclave and eager to know more about mainstream American ways. At a point when the clambake is already well under way and all the Portuguese guests had already arrived, we learn that "behind them came two women. They were not townspeople, but summer people, wearing long flowery dresses and big, wide-brimmed straw hats." The narrator goes on to note that a "ripple of distress passed through the Pico ladies sitting by the door" (28).

Although some of these fictional immigrants in Provincetown resist mainstream traditions and ways, the irony is that this episode 
highlights their appropriation of this "all American," New England ritual so as to suit their needs. On the one hand, it is incorporated into this community's Catholic calendar (the blessing of the fleet). On the other hand, it stresses the connection between food and religion in Portuguese American culture, an issue which we shall see ahead. Moreover, the clambake draws upon the way of life in an ethnic community. It allows for the community members to get together and, in the process, reminisce about the old country and revive some of its traditions:

John Joseph and I brought out the lobsters and clams and fish and bread and corn. Their smells spread a lushness in the air, and the women softened and talked and laughed as we all ate. Everyone celebrated my grandfather's cooking, and cartons of ale were now stacked along the duckpen fence. Sometime after the clatter and slosh of eating had subsided, Jaime Costa, Juney's younger brother, pulled his guitar out of its battered case, and in his ragged voice began singing fados, those sad, old-country songs of fate (29).

This quote is important for a number of reasons. On the one hand, it demonstrates how ethnic eating is a means to connect with the ancestral culture through music, but also an anchor for ethnic identity. On the other hand, it stresses the process of cultural hybridization this community is undergoing. Fado is not an Azorean song and it is not even popular there. It is sung in the U.S. Portuguese immigrant communities and it has been incorporated in Azorean-American culture. This quote stresses the way in which ethnic identity in the fictional world of Provincetown is kept alive through the preparation of food, growing vegetables in a garden ("corn"), and eating. These, in turn, anchor identity and allow it to hybridize in a new environment.

The second clambake is the climax of the novel since it draws all the people from this ethnic community together. It is held in chapter eighteen, the very last chapter in Leaving Pico. Everybody has gotten together to mourn John Joseph, who had perished at 


\section{Ethnic Studies Review Volume 31}

sea. As in most Greek tragedies, the people in Provincetown are eager for a catharsis. In this novel, consuming food not only allows this community to pay their respects to the family of the deceased person, but also to uplift their state of mind and feelings. Sadness and loss are, therefore, another motive for consuming ethnic foods, especially when what is at stake is eulogizing and remembering a loved one.

In Mass for the Grace of a Happy Death, Frank Gaspar also writes about a popular foodstuff available in most Portuguese communities in the United States, sweet bread (a yellow, sugared, egg-heavy cake), which can be eaten for dessert, or simply toasted with butter for breakfast or a late afternoon snack. In the poem "Acts," baking sweet bread is a community ritual that traditionally takes place the few days before Easter Sunday. In this poem, Gaspar shows how sweet bread and the ritual associated with baking it during Lent reinforces the bond between specific foodstuffs and religion in Portuguese and Portuguese American culture. Moreover, eggs are traditionally associated with Easter. This is due to their abundance on farms during this time of the year, Spring, and this might account for Portuguese women back home or in the American diaspora using them profusely during the Easter season. More than during any other time of the year, sweet bread is baked during this period not only for religious but cultural reasons. Currently, in Portuguese villages, women work very hard to have their Easter table with plenty of sweets, sweet bread, and other cakes so as to receive their guests and neighbors during the yearly Easter ritual of kissing the cross carried by the local priest and his acolytes, who go from house to house announcing the resurrection of Christ. After the brief prayer, everyone gathers around the table to eat and drink. This activity usually lasts for one or two afternoons (Easter Sunday and Monday) and the whole community takes the time to engage in this ritual by going from one house to the other, celebrating their happiness and religious beliefs, while eating and drinking together. In a new environment, the United States, this ancestral ritual is difficult to put into practice, but this poem also stresses this community's strong ties, given that the narrator's mother and a few other women were baking sweet 


\section{Silva-The Tastes from Portugal}

bread. Baking cakes together is also a means to celebrate friendship and unity in this community:

As if there were no bitterness in their lives, as if no dark ever slid outward from the sills of those kiltered windows, the house would suddenly fill with women and the rooms would float in heady yeasts while my mother, powdered to the wrists in flour, would pound the dough in the great bowl, yellow, sugared, egg-heavy, warm in the gossip and coal-smoke of a winter morning. ${ }^{10}$

While they waited a few hours for the dough to swell by the fireside, the women would resume their chores and return at a later time so as to start baking the sweet bread:

And the gravid bowl set by the chimney

filled each corner with lingering spirits, the sweet bread swelling, buttock, breast, belly, plump tub of the world where the women even then were softly disappearing into their envies and wishes... (19).

The overall ambiance of harmony and friendliness in this community is replete, especially when we learn that the men

also slipped toward shadows as they waited for the hot slabs tendered from the oven, greased with butter, to dredge in milked coffee after a freezing day at the wharves... (19).

In a poem laden with religious language, it is worth pondering the metaphorical connection Gaspar establishes between food, 


\section{Ethnic Studies Review Volume 31}

religion, and sexuality ("gravid"; "swelling"; "buttock"; "breast"; and "belly"). In "Acts," these elements provide additional layers of ethnic identity. The process the dough undergoes before the sweet bread is baked is rendered in terms of an analogy. It is metaphorically compared to the sexual act, where the dough is "pound [ed]" and "the gravid bowl" and its "swelling" contents "set by the chimney." These references are reminiscent of a pregnant woman during complete bed rest. As far as the religious imagery is concerned, it is undoubtedly associated with Christ's Last Supper. The old woman's blessing of the sweet bread before it is baked, its distribution after it is taken out of the oven, and the communal ritual of the men eating together reminds us of holy Eucharist:

and the oldest

among them all, maple-skinned, gaunt

under her rough apron, brushing

the heel of her hand in the Sign

of the Cross over still-rising loaves,

a devotion she would never again

make over loaves like these,

never again in exactly this way,

the earth, in the rife bounty

it heaps upon the favored, letting

go of all of this forever: If such

sweet bread were ever blessed or holy,

let them take it now, quickly - and eat (19).

Not only does this poem center on a popular Portuguese delicacy, it also highlights the Catholic fervor of the people living in this Portuguese American community.

In the writings under review, food plays an important role in preserving ethnic identity. Not only is this achieved through the connection between food and the homeland, food and music, the garden and the homeland, it is also through food and religion. In addition to Gaspar's poem "Acts," food and religion are also connected in Thomas J. Braga's two poems, "Codfish Cakes" and "Bacalhau," from Portingales (1981). His place in the Portuguese 
American tradition of life writing rests on this compelling collection of poems and on Borderlands (1994). Braga is the grandson of Portuguese immigrants from the island of São Miguel in the Azores. He was born in Fall River, Massachusetts, and was a Professor of French language and literature. Braga has also published Chants Fugitifs (1981), Coffee in the Woodwinds (1990), Crickers' Feet (1992), Litotes (1997), Motley Coats (2001), Inchoate: Early Poems (2003), and Amory: Six Dialogues and Six Poems (2006). Braga was one of the first Portuguese American voices to write about the complexities of being born a hyphenated American and writing in the English language. ${ }^{11}$

While Gaspar's "Acts" stressed the use of eggs to bake a popular Easter cake, sweet bread, Braga's "Codfish Cakes" and "Bacalhau" highlight the fish diet most Portuguese observe during Lent. By choosing to write about these issues, both poets believe that food and Catholicism are intimately related and a means to preserve ethnic identity in a country where ethnic minorities have been encouraged to assimilate and discard their distinctive ethnic traits. These poems also highlight how specific Portuguese Catholicism and other beliefs, social traditions, and ethnic foods are preserved within the Portuguese enclaves of America. In addition, "Codfish Cakes" points to the Catholic observance of a fish diet on Fridays during Lent. Since the symbolism of Lent centers on moderation, abstinence, and penance, eating meat on Fridays would be perceived as a disrespectful act because it is reminiscent of Christ's shedding of blood on the Cross:

No meat today, don't ask!

No red sacrifice, instead the sea

will confess our sins in white

make us pure in a frying pan. ${ }^{12}$

In the following strophe, Braga enumerates the ingredients which are used to make these codfish cakes:

It's Fri-day, herbs, black aprons

Dress friends - mackerel, flounder, cod 


\section{Ethnic Studies Review Volume 31}

Parsley, onions, green sauce anointed

Fill our souls with sanctity marine (29).

The final strophes make a parallel between the oil in which they are fried and the role of olive oil in such pivotal Catholic moments as, for example, baptism and extreme unction:

Codfish cakes sizzle in holy oils greasy hosts dished out to each in kitchens of briny Ports shawls chanting waves of the catch.

Salty patties, water, poesy, place make the sea our sod, sanctuary as we sail through centuries, grace, eating codfish cakes, kale, statuary (29).

This poem indirectly touches upon quintessential aspects of life in a Portuguese fishing community, which further characterize this culture. Traditionally, the widows put on "black aprons" or "shawls" so as to mourn their shipwrecked husbands. Others simply wear dark clothes all the time since there is no joy when a loved one is away for days or months at a time. Fishermen, their wives believe, only come back to life when coming ashore. The mood in this poem is marked by a certain feeling of fate ("fado") and nostalgia ("saudade"), aspects which, some believe, characterize the Portuguese temper. Often, codfish cakes are made at the expense of lives lost at sea, which enhances the notion of "fado" in Portuguese culture. The perils involved in catching codfish in Newfoundland for about half a year, the storms and the imminent shipwrecks, and the wives or mothers who long for their husbands or sons are aspects which this poem touches upon even if indirectly. With the sea possessing such a symbolical value in Portuguese culture (epitomized by Portugal's role in the Age of European Discoveries and its fishing subculture and traditions), the sea has, indeed, shaped the Portuguese outlook on life: that of a people subject to its whims. The phrase "make the sea our sod" 
highlights the sea as an important locale for several Portuguese, but it also suggests Braga's play on the sea as their god as well. From a Christian perspective, fishing is a very important activity since Christ associated with fishermen. In Matthew 4: 18-22, Christ invited Peter, Andrew, James, and John to join Him and they, in turn, became his disciples. In this passage as in the other gospels, Christ refers to Himself as a fisherman who was "fishing" for followers. For a devout Catholic people such as the Portuguese, fishing was seen as a sacred activity blessed by God. In addition, the poem's religious diction in such phrases as "red sacrifice," "confess our sins in white," "pure," "holy oils," and "sanctuary" further attest to these women's Catholic beliefs and how they cling to God since He is the only One capable of bringing their loved ones ashore. In times of abstinence and penance, codfish, the fiel amigo, or loyal friend, comes in handy since it can be cooked in a number of different ways, thus allowing for diversity during those long weeks of Lent.

In both poems, "Codfish Cakes" and "Bacalhau," fishing and cooking codfish are activities which foreground quintessential aspects in Portuguese American ethnic identity. "Bacalhau" is a good example of the Portuguese fondness for codfish, but also a hymn to all the fishermen who sail to Newfoundland to capture it:

In search of hallowed cod, all salted, all preserved, in high rubber boots shod, 'Guees sail, for brine reserved (45).

Compared to the previous poem, the ingredients utilized in the recipe(s) alluded to in the last three strophes are slightly different, which supports the idea that this fiel amigo is an important foodstuff in Portuguese gastronomy:

Hauled into port, the fish, loyal friends sacrificed, dressed in oils, eggs, the dish in garlic, onions diced 


\section{Ethnic Studies Review Volume 31}

with olives, potatoes, lemon and paprika, for some with tomatoes, Bacalhau America

in ethnic savours best.

With memories repast, dark seaweed spirits rest by sirens lured, barques past (45).

There are, at least, two codfish recipes which this poem suggests, namely Bacalhau à Brás and Bacalhau à Comes de Sá, which reinforces the notion of variety in Portuguese cuisine and the numerous ways in which codfish can be cooked. Although codfish cakes are a Portuguese delicacy, their taste might not be as pleasant especially when recalling those unfortunate sailors whose "spirits" and bodies were trapped in the "dark seaweed." By capitalizing "Bacalhau [codfish] America," Braga stresses its importance in Portuguese gastronomy and how these traditions are kept alive in the Portuguese ethnic enclaves of America, a land that has often been hostile towards Otherness. On occasion, this hostility has been expressed a propos the eating habits of most minorities. ${ }^{13}$

Braga attaches a sense of sacredness to the lives of these fishermen and their catch since they are constantly putting their health and lives at risk and, in the end, are exploited by the owners of the boats. The poem is also replete with religious overtones as in the phrase "hallowed cod." Braga stresses the Catholic fervor of the Portuguese through the Eucharistic connotations associated with eating it and the spirit of the Grail quest embedded in the poem (in such phrases as "in search of hallowed cod"). He also wishes to stress the perilous situations these men often encounter at sea. Whether they will or will not encounter what they are looking for lies in the hands of God. While Christ sacrificed His life to redeem sinners, these fishermen often sacrifice their lives to allow for this foodstuff to appear on the tables of most Portuguese or Portuguese Americans. Braga describes the importance of food in a letter: 
My food poems are about ingesting cultural values. After ethnics have forgotten the language of their ancestors, they still remember the "taste" of the "familial" foods which helps them to identify themselves as distinct from Anglos and other hyphenated Americans. Much the way the Madeleine worked for Marcel Proust to conjure up his personal past (Á la Recherche du Temps Perdu), so too my Portuguese food poems are a mnemonic aid, a link to my childhood through gustatory sensations. ${ }^{14}$

Braga's point on the role of ethnic food as a means to preserve identity and to establish a bridge with one's ancestral culture is similar to the one made by Gaspar. He then goes on to note that: The repetition of such words as "vinho," "caldinho," "bacalhau," "massa," "malassadas," etc. acquires a liturgical quality in my poetry suggesting a religious rite of saudade.

In this statement, Braga further establishes the parallel between food and religion in Portuguese culture and then goes on to note how wine on his grandmother's dinner table transported him to his youth, life in his ethnic community, and how it served as a liaison with mainstream life. For example, "vinho" is associated with Vovó's dinner table. It has a certain color, taste, aroma, an ambiance of sounds and images, a sarau. Wine, on the other hand, is what we purchased at the package store. It was always associated (at least in my mind) with what was outside the house, or what was advertised on TV. It's what we drank at restaurants, cocktail parties, with "gente da nação" (my grandmother's term for American born Anglos).

The two most often cited points concerning food and ethnicity in America - memory and retaining ethnic identity (see Magliocco) - are the ones Braga has mentioned in this quote. ${ }^{15}$ While food may be a powerful means to maintain ethnic identity, it is also how one connects with the past, especially in a situation where the ethnic subject can no longer verbalize any of the words pertaining to the ancestral language. Although the relationship between the 


\section{Ethnic Studies Review Volume 31}

Portuguese and the sea dates back a few centuries, this does not mean that one can only find fish dishes on a Portuguese or Portuguese American table. Gaspar and Braga showed a preference for fish and seafood dishes in their writings, but Katherine Vaz's Saudade (1994) begins with a barbecue, so as tostress the importance of meat in a Portuguese diet as well. Saudade is about a self-reliant deaf-mute young woman, Clara, who through much effort tries to regain the piece of land in Lodi, California, that her uncle Victor had bequeathed to her mother, Conceição Cruz. In the Azores, Father Teo Eiras had managed to convince her mother to sign the deed of the land over to the Catholic church. Afterward, both Clara, an orphan in her teens, and the priest, Father Teo Eiras, emigrate to California, and when she becomes a young woman, she seduces him and gets pregnant but, to her dismay, never becomes the legal owner of the land, which remains in the hands of the church.

Within Clara's saga to retrieve her land, there are also allusions to Portuguese culture and traditions. Saudade is also a story about how the values, culture, and literature of a country from the Old World have come into contact with those of the New World. Vaz attempted to bridge the literary traditions of both Portuguese and American literature; more specifically, the two novels concern a child that has been fathered by a priest. The American classic dealing with this matter is Nathaniel Hawthorne's The Scarlet Letter (1850); the Portuguese counterpart is Eça de Queiroz's O Crime do Padre Amaro (1875; Father Amaro's Sin). Vaz's second novel, Mariana, was published in 1997. This interest in a clergyman fathering a child is also present in the story "Original Sin" in Fado Other Stories, which won the 1997 Drue Heinz Literature Prize and is composed of twelve pieces, three of which are representative of Portuguese American themes: "Fado"; "My Hunt for King Sebastião"; and "The Remains of Princess Kaiulani's Garden."16 The barbecue episode takes place just before José Francisco, Clara's father (at this point, Clara had not yet been conceived), and his wife, Conceição Cruz, are hosting a farewell party for him. He was about to leave for his first fishing voyage to Portugal's mainland, in the fishing village of Nazaré. This episode stresses the importance of meat in a Portuguese diet as opposed to fish in the other texts. 
One of the characters, Henrique Cerqueira, José Francisco's "closest friend," has "milked cows for such interminable hours hoping to save money for America that his hands were swollen into bleached sacs, each with five teats. ${ }^{\prime 17}$ This character represents the thousands of Portuguese men who emigrated to California to work in its dairy industry. He had, we learn, brought green, white, and red wines and crabs,lobsters, and coins stuck in apples for good luck. He came bearing abrotea fish for grilling, black morcela sausages, salted tomatoes, pork with clams and red peppers, and eels killed with tobacco in the water to remove their slime. Instantly he was swept into an argument with Maria Josefa about the right way to cook pork (5).

The choice of foods for this barbecue substantiates Anderson's point about variety and the "innovative teaming"18 of fish, meat, seafood, and vegetables in Portuguese cuisine. Although Portugal is a relatively small country (both the mainland and the islands composing the archipelagos of Madeira and the Azores), its richness lies in the variety of regional foods and dishes. This diversity is well represented in the Portuguese American communities as well. Since Vaz is a Californian writer of Portuguese/ Irish-American descent and grew up in a cattle-breeding environment, it would make sense that she would include meat in her fictional meals. Reading Vaz's fiction adds another dimension to the representation of food in the writings from her Portuguese American cultural background. Should one only look, instead, for the representation of food in Braga's and Gaspar's writings, this would certainly be too reductive since they focus mostly on fish, kale soup, and sweet bread. In addition to meat products, Vaz also writes about the importance of sweets and desserts in Portuguese gastronomy. Reading all three authors leaves us with a sense of completeness and exposes us to the variety in Portuguese cuisine that we, in fact, encounter in all sorts of Portuguese cook books. ${ }^{19}$ And even though these middle-class American writers of Portuguese descent focus on foods and cuisines eaten by and prepared by mostly working class people - their immigrant ancestors - these diets and selections of food are exactly the same or are popular among middle-class or professional Portuguese Americans or native Portuguese in Europe, 


\section{Ethnic Studies Review Volume 31}

regardless of their social background. Most of these foodstuffs are made exactly the same way whether they are to be served in a Portuguese restaurant in, for example, the Ironbound section of Newark, New Jersey (or any other big Portuguese community in the United States) or in Portugal.

Saudade concerns the author's home state, California, even if it attempts to highlight the clash in values between the Old and New worlds. It also illustrates the Portuguese ways of life in rural California and their involvement in the local dairy industry. That is why meat, instead of a fish diet, features so strongly in this novel. But in Saudade and Mariana (1997), Vaz exhibits a stronger preference for the sweets and desserts made in Portuguese convents by nuns, a tradition dating all the way back to the seventeenth- and eighteenthcenturies. Without a doubt, this connection between food and the homeland, that is, between sweets and nuns is not unique to Portugal, but exists throughout the Catholic Mediterranean. Vaz, however, focuses on the Portuguese convent sweets since these are, most likely, the ones she is most familiar with. In Saudade, Clara, who has grown up in California and knows very little about her country of birth, Portugal, learns about the legend associated with these sweets:

"Long ago, in the convents of Portugal, the nuns starched their wimples and habits with egg whites.

Because wastefulness is a sin, they needed to dream up uses for the leftovers. That is how they came to invent the yolk-heavy desserts that are made to this day" (111).

As a means to connect with the ancestral food and tastes, in Saudade, we find Dr. Helio Soares helping Clara beat the egg into castles with sugar and salt and shaped the meringues on brown paper, and while the suspiros baked, they made dreams, boiling the milk and mixing in flour, sugar, and eggs. Her hair fell toward the spitting oil in a frying pan (202). This passage refers to at least two desserts: suspiros (sighs) and sonhos (dreams).

In the fictional world of Katherine Vaz's Mariana, convent 
sweets are very important. Vaz has picked up on a seventeenthcentury love story rendered to us in Portuguese literature through a nun, Soror Mariana de Alcoforado, titled Cartas Portuguesas. In Mariana, Vaz does not write a radically different story from the original one in Cartas Portuguesas. On the one hand, Vaz translated the love letters this Portuguese nun had written to the French officer, Noel Bouton, she had fallen in love with. On the other hand, she re-creates the ambiance in Southern Portugal, Beja, in the seventeenth-century as the Portuguese struggle, through the aid of the French, to break free from Spanish rule, which began in 1580 and ended in 1640. As for the desserts, we learn that various cooks were baking sweets and pastries in the convent's kitchen. As soon as they learn about this activity, Sister Mariana and Brites de Freire immediately slipped down to the kitchen, where the cooks were busy. They worked through the night, so that the delicacies they would sell to townspeople appeared as if by magic at sunrise. Egg whites were used to starch everyone's habits and wimples, which left so many yolks that they had to invent yolk-rich desserts to avoid the sin of wastefulness. In the cook's struggle to dream up new things from the same old substance, they had to rely on humour, giving their creations names such as Nuns' Bellies, Angels' Breasts, Abbots' Ears. Mariana and Brites de Freire were enthralled by this frieze from time immemorial, with women awake before daylight, working, inventing, amusing themselves. ${ }^{20}$

By focusing on convent sweets traditionally made by Portuguese nuns, Vaz tries to connect with her ancestral culture and provide an anchor for ethnic identity. In Mariana, not only does she open the door to Portuguese culture for an American audience interested in learning about it, she also whets their appetite for Portuguese food. The author has conveyed in an e-mail that her "grandfather from the Azores was a fine baker, and anything to do with Portuguese sweets reminds [her] quite directly of him." ${ }^{21}$ As a tribute to her grandfather, these sweets are also a means for her to tap into her senses for artistic purposes. As far as this issue is concerned, she has written that:

I very much like the names of desserts in Portuguese - 


\section{Ethnic Studies Review Volume 31}

Sonhos, Suspiros, and so on, but also the amusing ones, Breasts of Angels, Nuns' Tummies, etc. The very language of these seems inviting for a writer to use as if an ordinary dessert suddenly becomes not only whimsical but sensuous and entertaining and light hearted. (E-mail 21 March 2001)

She goes on to note that writing about food is a theme that appeals to her even if her creative writing students omit references to the senses in their own writing. She thinks this is ironic since our senses are exploited to the fullest when we, for example, daily turn our TV sets on. My years of teaching also showed me that students now very often neglect to include in their stories mention of these things-of-the-senses that are part of our lives alone or with others; food can be seen as a communion. ${ }^{22}$

For Vaz it is strange that contemporary students shaped by the media resist expressing how something in particular appeals to their senses. Food is perhaps the best means to do so publicly even if we try to keep our feelings within our own private realm.

In an interview for the Newark, New Jersey Portuguese American Newspaper, Luso-Americano, Vaz told her interviewer:

My mother, despite her Irish background, often cooked several Portuguese dishes. When I was still a child, my parents wrote a book containing Portuguese recipes.

They were so fond of preserving everything that was Portuguese. $^{23}$

In addition to "perpetuating one's cultural background and ethnicity," food, writes Pereira, is a means for "keeping the family together, a means to share something meaningful, and a part of one's life."

Convent sweets, Maria Isabel de Vasconcelos Cabral reminds us, are also a Portuguese cultural legacy in the sense that some of the ingredients utilized to make them are intimately related to and evocative of - the spices and foodstuffs the Portuguese sailors brought back with them from India during the Age of European 
Discoveries. ${ }^{24}$ Without Vasco da Gama's discovery of the sea route to India in 1498, it is unlikely that spices would have become so readily available to most European consumers. And convent sweets - I would further add - perhaps unknown to us, as well. Through her writing, Vaz - along with Gaspar and Braga - are irreplaceable ambassadors of Portugal on American soil because they share with Americans some of the best cultural nuggets (food; fado-singing; religious fervor; folklore; and literary allusions) the Portuguese have to offer to the world at large.

While food may play a similar role among the various ethnic backgrounds composing the American mosaic, in the particular case of the Portuguese American experience, it has its own specificities. Food is an important anchor for ethnic identity and a means to connect with times which have completely disappeared. While the profusion of seafood evokes the Portuguese ancestral seafaring cultural heritage, its consumption may also be a strong reason to bring people together to mourn some fisherman lost at sea or simply a motive to reminisce about the old country and revive some of its traditions. Most importantly, food stresses the bond between specific foodstuffs (sweet bread and codfish cakes) and religion in Portuguese culture and how these are intimately related.

As the Portuguese become more and more assimilated into the mainstream, the very last Portuguese elements which resist this process are one's last name and ethnic food. With Thomas Braga, Frank Gaspar, and Katherine Vaz, for a while, Portuguese Americans will feel reassured that their traditions, culture, food, and way of life in America will survive. But only time will tell if the foodstuffs discussed in this essay will stand the test of time, that is, if within a few decades from now Americans will still be able to identify them as being of Portuguese origin. Or, instead, will these be marketed as "American" products just as sweet bread and the Portuguese sausage, linguiça, are nowadays in many supermarkets and delicatessens across the nation? Regardless of what will eventually happen, and as long as we keep on toasting one another with a glass of Port wine, these moments of happiness evoke another important Portuguese contribution to the entire 


\section{Ethnic Studies Review Volume 31}

world.

\section{Works Cited}

Abrahams, Roger. "Equal Opportunity Eating: A Structural Excursis on Things of the Mouth." Ethnic and Regional Foodways in the United States: The Performance of Group Identity. Eds. Linda Keller Brown and Kay Russell. Knoxville: The $U$ of Tennessee P, 1984. 19-36.

Anderson, Jean. The Food of Portugal. New York: William Morrow, 1986.

Biasin, Gian-Paolo. The Flavors of Modernity: Food and the Novel. Trans. Gian-Paolo Biasin. Princeton NJ: Princeton UP, 1993.

Braga, Thomas J. Portingales. Providence RI: Gávea-Brown, 1981. ---. Letter to the author. 27 July 2001.

Cabral, Maria Isabel de Vasconcelos. O Livro de Receitas da Última Freira de Odivelas. Lisboa: Editorial Verbo, 1999.

Gabaccia, Donna R. We Are What We Eat: Ethnic Food and the Making of Americans. Cambridge MA: Harvard UP, 1998.

Gaspar, Frank X. The Holyoke. Boston: Northeastern UP, 1988.

---. Leaving Pico. Hanover NH: UP of New England, 1999.

---. Mass for the Grace of a Happy Death. Tallahassee FL: Anhinga P, 1995.

---. Night of a Thousand Blossoms. Farmington ME: Alice James Books, 2004

---. E-mail to the author. 2 October 2001.

Magliocco, Sabina. "Playing with Food: The Negotiation of Identity 
Silva-The Tastes from Portugal

in the Ethnic Display Event by Italian Americans in Clinton, Indiana." Studies in Italian American Folklore. Ed. Luisa Del Giudice. Logan UT: Utah State UP, 1993. 107-26.

Modesto, Maria de Lourdes. Cozinha Tradicional Portuguesa. Lisboa: Editorial Verbo, 1993.

Oliver, Mary in Frank Gaspar. The Holyoke. Boston: Northeastern UP, 1988.

Pap, Leo. The Portuguese-Americans. Boston: Twayne, 1981.

Pereira, Maria do Carmo. "A Autora de Fado and Other Stories, Saudade e Mariana: 'Quando Tinha Doze Anos Já Sabia Que Queria Ser Escritora'." Luso-Americano 16 March 2001: 6-7.

Santiago, Luís. Cozinha Regional da Beira Litoral. Mem Martins: Publicações Europa-América, n.d.

Silva, Reinaldo Francisco. "Frank Xavier Gaspar." The Encyclopedia of Multiethnic American Literature. Ed.

Emmanuel S. Nelson. 5 vols. Westport CT: Greenwood, 2005. [Vol. 2: pp. 798-801].

---. "The Ethnic Garden in Portuguese-American Writing." The Journal of American Culture 28.2 (2005): 191-200.

---. "Katherine Vaz." The Greenwood Encyclopedia of Multiethnic American Literature. Ed. Emmanuel S. Nelson. 5 vols. Westport CT: Greenwood, 2005. [Vol. 5: pp. 2208-10].

---. "Portuguese American Literature and Anticlericalism: Katherine Vaz's Reshaping of the Tradition." Gávea- Brown: A Bilingual Journal of Portuguese-American Letters and Studies XXII-XXII (2001-2): 46-63. 


\section{Ethnic Studies Review Volume 31}

---. "Thomas J. Braga." The Greenwood Encyclopedia of Multiethnic American Literature. Ed. Emmanuel S. Nelson. 5 vols. Westport CT: Greenwood, 2005. [Vol. 1: pp. 311-12].

Valente, Maria Odette Cortes Valente, Cozinha Regional Portuguesa. Coimbra: Almedina, 1986.

Vaz, Katherine. Fado \& Other Stories. Pittsburgh PA: U of Pittsburgh P, 1997.

---. Mariana. London: Flamingo, 1997.

---. Saudade. New York: St. Martin's, 1994.

---. E-mail to the author. 21 March 2001.

---. E-mail to the author. 2 November 2001.

\section{Notes}

1 Jean Anderson, The Food of Portugal (New York: William Morrow, 1986), p. 10.

2 See Reinaldo Francisco Silva, "Frank Xavier Gaspar," The Greenwood Encyclopedia of Multiethnic American Literature. Ed. Emmanuel S. Nelson. 5 vols. Westport CT: Greenwood, 2005. [Vol. 2: pp. 798-801].

3 See Mary Oliver's introduction in Frank X. Gaspar, The Holyoke (Boston: Northeastern UP, 1988), p. xi. Further references to poems in The Holyoke are from this edition.

${ }^{4}$ See Reinaldo Francisco Silva, "The Ethnic Garden in Portuguese-American Writing." The Journal of American Culture 28.2 (2005): 191-200.

${ }^{5}$ Frank X. Gaspar, Leaving Pico (Hanover NH: UP of New England, 1999).

${ }^{6}$ E-mail to the author. 2 October 2001.

7 See Maria Odette Cortes Valente, Cozinha Regional Portuguesa (Coimbra: Almedina, 1986), pp. 153-54.

${ }^{8}$ Gian-Paolo Biasin, The Flavors of Modernity: Food and the Novel, trans. GianPaolo Biasin (Princeton NJ: Princeton UP, 1993), p. 13. 


\section{Silva-The Tastes from Portugal}

9 In the story "Fado," in Fado \& Other Stories (Pittsburgh PA: U of Pittsburgh P, 1997), pp. 97-8, Katherine Vaz defines fado in the following manner: "The fados wailing from our record players remind us that without love we will die, that the oceans are salty because the Portuguese have shed so many tears on their beaches for those they will never hold again."

${ }^{10}$ Frank X. Gaspar, Mass for the Grace of a Happy Death (Tallahassee FL: Anhinga P, 1995), p. 19.

11 See Reinaldo Francisco Silva, "Thomas J. Braga" in The Greenwood Encyclopedia of Multiethnic American Literature, ed. Emmanuel S. Nelson. 5 vols. Westport CT: Greenwood, 2005. [Vol. 1: pp. 311-12].

12 This poem and the subsequent ones by Thomas J. Braga are included in Portingales (Providence RI: Gávea-Brown, 1981), p.29.

${ }^{13}$ Donna R. Gabaccia has noted in We Are What We Eat: Ethnic Food and the Making of Americans (Cambridge MA: Harvard UP, 1998), especially on pages 203; 8; and 9 that in America, food and ethnic stereotyping have been used to demean Otherness: "When we want to celebrate, or elevate, our own group, we usually praise its superior cuisine. And when we want to demean one another, often we turn to eating habits; in the United States we have labelled Germans as 'krauts', Italians as 'spaghetti-benders,' Frenchmen as 'frogs,' and British as 'limeys'." On this issue, see also Roger Abrahams' article, "Equal Opportunity Eating: A Structural Excursis on Things of the Mouth," in Ethnic and Regional Foodways in the United States: The Performance of Group Identity, eds. Linda Keller Brown and Kay Mussell (Knoxville: The $U$ of Tennessee P, 1984): 19-36. Rogers has noted that in America, Chicanos/as have been associated - and often denigrated - for their tamales, while the Frenchmen have been stereotyped as eaters of frog legs, and Southern blacks as possum-eaters. The Portuguese, too, have not been exempt from such a treatment as well. My childhood recollections of Newark, New Jersey of the Portuguese as sardine and codfish eaters along with the "pork chop" and "pork and cheese" ethnic slurs are still imprinted on my mind. Fortunately, these days belong to the past.

14 Thomas J. Braga. Letter to the author. 27 July 2001.

${ }^{15}$ See Sabina Magliocco's article, "Playing with Food: The Negotiation of Identity in the Ethnic Display Event by Italian Americans in Clinton, Indiana" in Studies in Italian American Folklore, ed. Luisa Del Giudice (Logan UT: Utah State UP, 1993): 107-8. See also Leo Pap, The Portuguese-Americans (Boston: Twayne, 1981), pp. 213-14.

${ }^{16}$ For more background information on Saudade, see Reinaldo Francisco Silva, "Portuguese American Literature and Anticlericalism: Katherine Vaz's Reshaping of the Tradition," Gávea-Brown: A Bilingual Journal of Portuguese-American Letters and Studies XXII-XXIII (2001-2): 46-63. See also Reinaldo Francisco Silva, 


\section{Ethnic Studies Review Volume 31}

"Katherine Vaz," in The Greenwood Encyclopedia of Multiethnic American Literature. Ed. Emmanuel S. Nelson. 5 vols. Westport CT: Greenwood, 2005 [Vol. 5: pp. 2208-10].

17 This quote and the subsequent one can be found in Katherine Vaz's novel, Saudade (New York: St. Martin's, 1994), p. 4.

${ }^{18}$ See Anderson, p.12.

${ }^{19}$ See, for example, Maria de Lourdes Modesto's, Cozinha Tradicional Portuguesa (Lisboa: Editorial Verbo, 1993) or even Luís Santiago's Cozinha Regional da Beira Litoral (Mem Martins: Edições Europa-América, n.d.).

${ }^{20}$ See Katherine Vaz's Mariana (London: Flamingo, 1997), p. 52. In my view, Vaz is not correct. "Angels' Breasts" must be her translation of "papos de anjo." The "papos" of children - as well as angels - are their bellies. No iconography in Portuguese ever represented angels with breasts. In the case of "Nuns' Bellies" ("barrigas de freira"), the word is "barriga" because nuns are adults. "Papo" is for babies or children. One can also use "papo" with adults, but most often in a metaphorical sense. I would like to thank the anonymous reviewer(s) of this manuscript for calling my attention to this detail and for helping me hone my overall argument in this essay.

${ }^{21}$ Katherine Vaz. E-mail to the author. 2 November 2001.

22 Katherine Vaz. E-mail to the author. 21 March 2001.

${ }^{23}$ See Maria do Carmo Pereira, "A Autora de Fado and Other Stories, Saudade e Mariana: 'Quando Tinha Doze Anos Já Sabia Que Queria Ser Escritora', LusoAmericano 16 March 2001: 6-7; my translation; the original can be found on page 7 as well as the subsequent quote, which I have also translated.

${ }^{24}$ See Maria Isabel de Vasconcelos Cabral's book, O Livro de Receitas da Última Freira de Odivelas (Lisboa: Editorial Verbo, 1999), p. 45. 